\title{
Article
}

\section{The Impact of Government Policy on Macro Dynamic Innovation of the Creative Industries: Studies of the UK's and China's Animation Sectors}

\author{
Zheng Liu ${ }^{1,2}$
}

Citation: Liu, Z. The Impact of Government Policy on Macro Dynamic Innovation of the Creative Industries: Studies of the UK's and China's Animation Sectors. J. Open Innov. Technol. Mark. Complex. 2021, 7, 168. https://doi.org/10.3390/ joitmc7030168

Received: 5 June 2021

Accepted: 1 July 2021

Published: 2 July 2021

Publisher's Note: MDPI stays neutra with regard to jurisdictional claims in published maps and institutional affiliations.

Copyright: (C) 2021 by the author. Licensee MDPI, Basel, Switzerland. This article is an open access article distributed under the terms and conditions of the Creative Commons Attribution (CC BY) license (https:/ / creativecommons.org/licenses/by/ $4.0 /)$.
1 Cardiff School of Management, Cardiff Metropolitan University, Cardiff CF5 2YB, UK; zliu@cardiffmet.ac.uk

2 Centre of Innovation and Development, Nanjing University of Science and Technology,

Nanjing 210094, China

\begin{abstract}
With digitalization and the support of policies, the creative industries have shown rapid growth in the last 20 years. Open forms of collective learning, user engagement and social networks have become popular to generate IPs and values. Meanwhile, government policy can support the sectors through subsidies, regulations, standardization, and protections at regional and national levels. This paper aims to explore the role of government policy in the innovation of creative industries from a macro dynamic perspective. The research method combines a structured literature review, a secondary document review of industry reports and government policy, and thematic content analysis. Through in-depth studies of the UK's and China's animation sectors, the paper identifies key elements of closed innovation, social innovation, and open innovation systems in the market. Comparisons of national government policies since 2000 reveal different approaches for countries where creative sectors are well-established, and for those starting with limited knowledge resources. A dynamic model is developed to address the evolution of macro dynamic innovation systems and the role of policies as interactive mechanisms. Practical implementation and future research areas are also suggested.
\end{abstract}

Keywords: innovation ecosystem; government policy; creative industries; open innovation

\section{Introduction}

With digitalization, cross-function collaboration, open innovation and user engagement, creative industries have been transformed greatly over the past 20 years. Companies use various internal and external resources to configure their value chains, in order to develop competitive advantages. Through technology convergence, the arts, media and design sectors form interactive relationships, leading to service-based, design-led and idea-driven characteristics [1]. With the establishment of the Department for Culture, Media and Sport (DCMS) in 1997, the UK government proposed a holistic framework to understand cultural and creative industries. In 1998, it was the first attempt on the government level to measure the value of the creative economies, with the mappings of 13 areas, namely advertising, architecture, the arts and antiques markets, crafts, design, designer fashion, film, interactive leisure software, music, performing arts, publishing, software, television and radio [2]. The creative industries, also known as cultural industries, can be defined as "industries which have their origin in individual creativity, skill and talent and which have a potential for wealth and job creation through the generation and exploitation of intellectual property" [3]. According to the United Nations Conference on Trade and Development (UNCTAD) [4], the creative economy's contribution to world trade doubled from $\$ 208$ billion in 2002 to $\$ 509$ billion in 2015. While the USA and Europe remain active players, China as the world's largest emerging market has demonstrated a dramatic increase in their cultural products and service trading, with an annual growth rate of $14 \%$ currently [4]. 
With diverse product ranges, creative industries show different business models across countries. One representative sector is the animation industry, which combines media, film, and character businesses. The UK's creative industries witness strategic alliance among small and medium-sized enterprises (SMEs), open innovation and collaboration among university, industry, customer and service providers, with the government mainly serving as a catalyst for change. Its animation sector once faced global competition. However, with the government introducing the Animation Tax Relief (ATR) policy in 2013, the industry has generated original intellectual properties (IPs), growing together with the TV sector [5]. In China, animation companies are latecomers due to their lacking IPs and brand recognition. Since 2000, the Chinese government has made great efforts to nurture this sector, demonstrating a different approach from countries where the industry has already been established. Recently, with digitalization and cluster effects, the creative industry innovation system in China has been transformed towards more knowledge-based models. Technologies such as ultra-high definition visual effects, online media, tablets and smartphones, visual reality, cloud computing, and distribution networks are speeding up the evolution of animation production and its products. The expansion of the gaming industry, and the user experience and service sectors also demonstrate market potentials. While traditional government policies such as subsidies, copyrights, trading agreements and quotas can encourage R\&D, knowledge integration, and IP protection in Europe, these approaches are challenged by Asian countries where IP protection is relatively loose, and instead policies can stimulate knowledge sharing and open innovation [6].

At the micro level, innovation is an integral part of organizations' business models and strategies. At the macro level, factors such as policy, culture, and technology can influence the structure and performance of regional or national innovation systems. In fact, innovation systems at regional or national levels can be highly dynamic, along with the interaction, changes and evolution of firms, universities, policy makers, market demand, and society, the combination of which can be referred to as the macro dynamic innovation system $[7,8]$. Among them, policy plays an important role. However, the exact linkage of government policy to the forming, developing and sustaining of the creative industries at the macro dynamic innovation system level is not clear. Moreover, a comparison is needed between countries with mature creative industries (such as the UK) and China, where initial innovation resources are limited. Thus, this paper aims to explore the role of government policy in macro dynamic innovation systems through studies of the animation sectors of creative industries in the UK and China. There are three specific research questions: (1) What are the features of the macro dynamic innovation system in the animation industry? (2) What are the roles of government policy at each stage of the animation industry's macro dynamic innovation system? (3) How can policies influence transformations among different patterns of the macro dynamic innovation system?

The paper is structured as follows. After this introduction, Section 2 provides the theoretical foundation of macro dynamic innovation and innovation policy. Section 3 concerns the research design and methodology. In Section 4, data analysis is conducted followed by further discussion. Section 5 is the conclusion of this research.

\section{Theories of the Macro Dynamic Innovation System and Innovation Policy}

\subsection{Innovation as System and Ecosystem}

While traditionally, large firms favor in-house research and development (R\&D) and innovation, known as closed innovation, open innovation describes a model of firms absorbing resources and exchanging knowledge actively beyond their boundaries [9]. At the company level, open innovation is classified as inbound innovation, meaning knowledge flow from the outside-in, and outbound (inside-out) [10]. Inbound activities include IP in-licensing, contracted R\&D services, specialized open innovation intermediaries, idea and start-up competitions, supplier innovation awards, university research grants, customer and consumer co-creation, crowdsourcing, publicly funded R\&D consortia, and informal networking [10]. Outbound open innovation is seen through joint-venture activities, 
spin-offs, corporate business incubation, selling market-ready products, IP out-licensing, participation in standardization (public standards), and donations to commons or nonprofits [10]. With public and user participation, the concept of social innovation emerges to connect creativity, solution development, and business changes with social and environmental needs, involving new forms of collaboration among individuals and organizations such as governments [11].

Alongside digital transformation, innovation is no longer seen as a linear process, but as entailing more feedbacks of people, organizations, and sectors, which co-creates an ecosystem [12]. The view of the business ecosystem describes firms collectively working together as a complex business community to deliver innovations to the market, through the evolution stages of birth, expansion, leadership, and self-renewal [13]. Innovation ecosystems further focus on upstream and downstream components to support innovation through interdependent interaction [14]. At the macro level, the macro dynamic innovation system model, known as the open innovation economy system (OIES), highlights the interactions among three sub-systems, namely the open innovation system (OIS), closed innovation system (CIS), and social innovation system (SIS) [7]. To be specific, The OIS refers to an innovation system that operates through SMEs and start-ups' collaboration. The CIS is led by large firms conducting R\&D internally, and delivering products and services to the market. The OIS involves social enterprises and independent third sectors for social value and society connection. While an evolutionary path is normally observed from OISs to CISs, SISs, and back to OISs, mutual transformations among the innovation systems are possible. Through strategic alliance, SMEs can absorb resources, converting OISs to CISs. Corporate venture capital investment, spillover activities, and open platforms can drive the direction from CISs to OISs. As large firms consider corporate social responsibility (CSR), CISs can move towards SISs. Through social value planning, and connections between technology and the market, social innovation can drive large companies to redesign their business models, and thus direct benefits from SISs to CISs. When SMEs join the social innovation economy as knowledge suppliers, the transfer from SISs to OISs takes place, as seen in the case of sharing economies [7].

Open innovation activities are observed as territorial dynamics of cultural and creative industries [15]. On one hand, creative industries are based on knowledge resources, and innovation and entrepreneurship ecosystems [15]. On the other hand, interactive relationships can be formed within and outside the sectors, institutions and users, which results in cross-boundary knowledge exchange $[15,16]$. Through a case study of a Chinese animation firm, it has been found that whereas large companies develop internal R\&D resources through open platforms and flexible project management, SMEs can build up capabilities collaboratively [17]. This provides an approach for latecomers with limited IPs [17]. At the regional level, creative cities with digital technology support can generate cluster effects, becoming an open innovation platform [15]. Through resource sharing, firms can overcome the contradiction between open access and IP protection, obtaining collective guarantees of IPs $[15,18]$ and thus reducing costs and risks [15]. Knowledge spillovers also benefit the creative industries, due to learning, skill development, projectbased collaboration, and the mobility of the labor market [19]. Product spillover sectors between software and hardware can be another effect of open innovation [15]. Through nonprofitable activities, industries can develop interactive relationships with user communities, who in return contribute to the innovation process through collective creation [15].

\subsection{Government Innovation Policy}

Innovation policy tools can be divided into supply-side instruments which influence knowledge generation, and demand-side instruments which speed up knowledge diffusion through increasing market demand [20]. Typical supply-side polices include public $\mathrm{R} \& \mathrm{D}$, funding, tax incentives, risk investments, personnel training, improving research centers, infrastructure, and industry clusters [21]. The Organization for Economic Cooperation and Development (OECD) [22] identifies six main demand-side policies, which 
are measures to stimulate private demand for innovation, public procurement policies, pre-commercial procurement, innovation inducement prizes, standardization and standards, and regulation. A demand-oriented policy can cultivate an open innovative culture, promoting new industries [23] and strengthening governance [24]. In addition, there are environmental-side tools such as law, finance and tax systems to improve the regulation environment for innovation [16]. In Li et al.'s [25] comparative studies on Russia and China's innovation policies, policy instruments are specified as supply-side (support for SMEs, fiscal support and subsides, financial support, infrastructure, human resources and international collaboration), demand-side (public procurement, industry-university-R\&D institution collaboration, standardization), and environmental-side instruments (administrative support, IP protection, tax incentives). Dynamically, innovation policies have experienced evolution from Frame 1 (Policy 1.0) innovation for growth, meaning centralized policies to promote production and consumption, to Frame 2 (Policy 2.0) national systems of innovation, meaning decentralized policies to encourage entrepreneurship and networks, and now towards Frame 3 (Policy 3.0) transformative changes emphasizing social needs and sustainability [26]. Typical practices of Policy 1.0 include research funds, mission-led research programs, favorable tax treatment, direct subsidies to specific industries, IP protection, foresight activities for selection, and education for research careers [26]. Policy 2.0 practices involve the central government building science hubs, investments in new technology-based firms, improving alignment among innovation actors, conditional funding to university, business and public research laboratories, encouraging research networks, foresight activities to encourage communication and coordination, cultivating entrepreneurship and the use of new technologies, technology diffusion by connecting supply and demand, and education and training with the aim of supporting the absorptive capacities [26]. While Policy 1.0 and 2.0 are from historical contexts, Policy 3.0 captures an emerging trend [26]. To face social and environment challenges when developing innovation policies, Frame 3 suggests engagement and networking between public, private and third sectors; user-involvement as producers, legitimates, and contributor of new demands; learning; societal experimentation including grassroots innovation; social welfare. Comparing them with Policy 3.0, studies on Sweden innovation policies suggest four challenges, which are directionality, experimentation, demand articulation, and policy coordination and learning [27]. Directionality refers to shared visions, and demand articulation requires both direct approaches such as funding, and indirect approaches such as the establishment of interaction platforms [27]. As for policy learning and coordination, there is a shift from the sectoral specialization approach to cross-sectorial integration and coordination [27]. Studies on EU practices address the increasing importance of public policies to promote links between science and innovation [12]. It is highlighted that apart from providing funding, public authorities should guide companies to better understand the regulatory framework as an after-sales service [12]. The awareness of social innovation enables idea and value exchange among nonprofits, businesses, and governments, as the role of government can move away from regulator towards collaborative supporter [28].

As for the creative industries, national policies can define the legal and institutional conditions, including ownership, content regulations, intellectual property, and communications infrastructures [29]. For example, the blooming of the UK film industry is largely due to the tax relief scheme [30]. Asset sharing, collective business models, and cluster effects can be driven by policies [15]. Public procurement, investment, public-private partnerships, regulations, and fiscal and financial policies can also influence the degree of openness and innovation in the creative industries [15]. Evidence suggests that there is a current trend from hard-law and state-subsidized policies towards soft-law and governance, leading to self-regulation [29]. The indirect promotion of creating and encouraging entrepreneurship are key strategies in the UK's creative economies [29]. Market-based regulations through contracts, licensing, design rules, and performance indicators are other examples of soft-laws and governance [29]. Comparative studies on Korea's and France's film industries indicate that neither protections, such as quota systems, nor promotions, 
such as abundant subsidies, can contribute to innovation, and instead government policy should be more balanced [6]. With the digitization of media content, there is debate on the degree of IP protection [29]. While the Hollywood models favor strong IP protection, public education of the value of creative industries, encouraging local innovation, and developing sustainable strategies are important in developing countries [29].

\section{Research Design and Methodology}

Various theories present the features of close innovation, open innovation, and social innovation at the macro level with the OIES model. Current research also shows the influence of government policy on the creative industries. However, how different policies can drive the changes of the macro innovation system is not clear. This paper aims to explore the role of government in forming and developing macro level innovation ecosystems in the creative industries, with a comparison made between the UK, where the industries are more developed, and China, where the industries is emerging. The research method combines a structured literature review, secondary document review, and thematic content analysis, which can provide details and in-depth understanding of issues which are underexplored, and thus guide the theory building. The research design is shown as Figure 1.

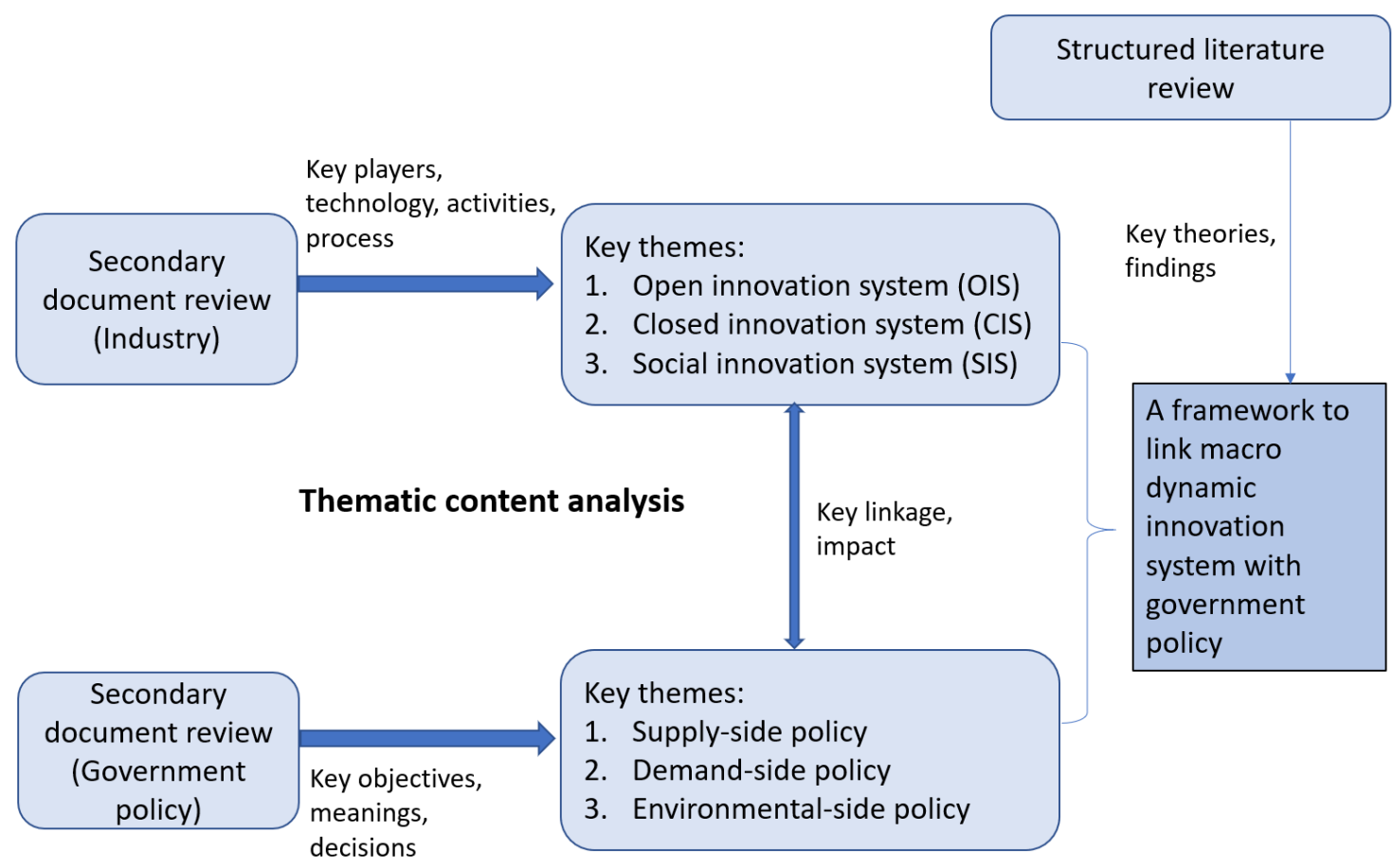

Figure 1. Research design.

First, a structured literature review is conducted with the aim of identifying key connections between creative industries' innovation and government policies covered by current research, and identifying the research gap. By using 'creative industries' and 'innovation' as the key words appearing in abstracts or author-supplied abstracts to search publications in the database of Business Source Premier and EBSCO, it turns out there are 67 papers published since 1980 as peer-reviewed journal papers. Then, the papers are further screened according to whether their focus is on micro level innovation or macro level innovation. Most micro level or organizational-level innovation studies concern knowledge absorption and management [31,32], business model innovation [33,34], digital transformation [33,35], entrepreneurial culture and partnerships [36,37], and people management [38]. There are 12 papers investigating macro-factors. Among them, regional employment growth as a driver and consequence of innovation [39,40], and the innovation 
of the creative industries, can have a positive impact on economic evolution and sustainability overall [41-43]. Of these 12 papers, 7 papers specifically explore macro-factors, including policies which influence innovation in creative industries, and thus they are closely related to this research. These papers are examined, with details and key findings summarized, in Table 1, which provides important theoretical foundations for this research It is seen that policies and institutions play essential roles in shaping regional and national macro innovation systems of the creative industries, and companies' innovation strategies are influenced by macro-factors. Multi-sided innovative actors and co-emergence innovation are new trends in the creative industries, together with digital transformation, university participation, and user engagement.

Table 1. Key findings of macro level innovation in the creative industries.

\begin{tabular}{ll}
\hline Paper & Key Findings \\
\hline Klement and Strambach [44] & $\begin{array}{l}\text { Policies need to analyze not only aggregate data but also the } \\
\text { composition of regional symbolic knowledge bases, which } \\
\text { are related or not directly related to the creative industries. }\end{array}$ \\
\hline Feuls [45] & $\begin{array}{l}\text { Innovation in the creative industries is not a linear } \\
\text { development process, but a culinary system involving } \\
\text { relations of everyday practices that define and transform } \\
\text { its value. }\end{array}$ \\
\hline Zhou et al. [46] & $\begin{array}{l}\text { Central government-funded research projects show an } \\
\text { inverted U-shaped effect on both firms' radical innovation } \\
\text { and incremental innovation in the creative industries. Local } \\
\text { government-funded projects have an inverted U-shaped } \\
\text { effect on firms' incremental innovation, but no significant } \\
\text { effects on firms' radical innovation. }\end{array}$ \\
\hline Policies need to integrate creative occupations into firms \\
across the whole economy.
\end{tabular}

Second, an industry-related secondary document review is conducted as the main approach of collecting data. It focuses on the UK's and China's animation sectors due the following reasons: (1) This sector delivers tangible products and services. (2) It shows clear stages of the value chain, from design, production, distribution, to service. (3) The animation industry is growing fast globally, demonstrating different characteristics at national levels. Thus, a potential comparison can be made from national policy levels. (4) This industry has been recently transformed with technology advancements, digitalization, platform-based collaboration, user engagement, which all show dynamic innovation features. Through a review of industry reports and websites, innovation activities are identified along with the value chain of the animation industry, namely creation/design, manufacturing/production, distribution/marketing, and communication/service. Then, we went through a content thematic analysis, following the steps of generating initial codes from the text, sorting the different codes into potential themes by providing a shorter list 
of categories, grouping the categories together, and reviewing and refining themes [51]. Three themes, consistent with Yun's [7] framework, are generated, in terms of the CIS, OIS, and SIS. Specifically, the CIS means the predominance of large animation companies which lead the innovation. The OIS refers to collaboration among SMEs, and the SIS shows the features of user engagement and the popularity of using social media in the animation industry. Details of key players, such as leading animation firms, key technologies, and activities and processes are synthesized against the key themes.

Third, documents of government policies are reviewed, which include national level policies issued by the China and UK governments since 2000, relating to creative industries and the animation industry. A similar thematic content analysis is then conducted by examining the objectives, meanings, context and decisions of each policy [51], which are then compared with the characteristics of supply-side, demand-side, and environmentalside instruments generated from the literature review (Table 2). It is also noted that supply-side policy is reflected in the Policy 1 framework (Frame 1.0) [26], whereas demandside policy, especially the involvement of users and social innovation, is consistent with Policy 2 (Frame 2.0) [26]. Environmental-side policy is synthesized from various studies and can be reflected in Policy 3 (Frame 3.0) [26] with its sustainability orientation. Further links are made among the policy instruments and the macro innovation systems of CISs, OISs, and SISs, with emphasis on the impact of policies on innovation, and the interaction mechanism at each development stage.

Table 2. Innovation policy categories.

\begin{tabular}{ll}
\hline Category & Sub-Category \\
\hline S1: Public funded R\&D and mission-led research [21,26] \\
S2: Fiscal/ financial support and subsides [25,26] \\
S3: Favorable tax treatment [21,26] \\
S4: Establishing science hubs and industry clusters [21,26] \\
S5: Supporting SMEs and start-ups [25,26] \\
S6: Infrastructure support, e.g., improving research centers [21,25] \\
S7: Education for research careers [26] \\
S8: Personnel training [21] \\
D1: Stimulating private demand for innovation [22] \\
D2: Public procurement [22,25] \\
D3: Pre-commercial procurement [22] \\
D4: Innovation inducement prizes [22] \\
D5: Industry-university-R\&D institution collaboration [22] \\
D6: Standardization and regulation [22,25] \\
E1: Law, finance, tax systems to improve the environment [21,25,29] \\
E2: Content regulations, quota, IP protection [25,27,29] \\
E3: Administrative, sharing platforms, infrastructure and service \\
support [17,21,25] \\
E4: User-involvement as producers, legitimates, and demand \\
contributors [26] \\
E5: Improving alignment and cross-sectorial coordination [26,27] \\
E6: Promotion of entrepreneurship and innovation culture [26,29]. \\
E7: Soft-law and governance, leading to self-regulation [29] \\
E8: Public education of the industry values with the aim of \\
sustainability [29] \\
\hline
\end{tabular}

\section{Findings and Discussion}

\subsection{The Macro Innovation System of the Animation Industry}

The UK has a long tradition of animation production. At the beginning of the 2000s, firms such as Aardman produced influential animation TV series, jointly distributing products to overseas markets with DreamWorks. Post-production companies such as Framestore and Double Negative demonstrated advanced expertise in visual effects and computer graphics animation, which attracted local and international partners. Due to 
international competition and the rise of emerging economies, the UK's animation sector was once in retreat. However, since the government introduced the ATR policy in 2013 and extended the scheme to children's programming in 2014, the industry started re-blooming immediately [52]. Apart from leading firms, SMEs and independent artists have also showed competencies of design, playwriting, music production, post-production, and special effects. Knowledge exchange and project-based collaboration became themes of innovation [53].

Since 2014, UK distributors, including TV broadcasting channels and online platforms, have engaged with sales and IP management of animation products. There are 22 children's broadcasting channels, the biggest (CBBC, CBeebies, CITV) distributing more than $80 \%$ of the animation products made in the UK [52]. TV channels actively support original design and production through their regulations. Digital animation-related platforms and technology innovation are also supported by public funding [54].

As the UK's animation sector becomes a global leader, spillover impacts have delivered significant value, particularly through merchandized sales, since 2014. Shaun the Sheep, Peter Rabbit, and Peppa Pig are examples of shows that generate revenue 150 times of their original production budget through IP management and mechanization [5]. Industrial and social events have become influential. Founded in 2003, the London International Animation Festival (LIAF) is the largest animation-related festival in the world, each year showcasing around 250 animation films from over 30 countries. This annual 10-day event involves premieres, retrospectives, interviews with filmmakers, workshops, audience voting, and awards, and has become a forum to support innovation across industries and the public $[54,55]$. Online events also facilitate IP generation, with collaboration across sectors including performance arts, and game and virtual arts [53]. Industrial associations, such as Animation UK (established in 2016), Animation Alliance UK, and non-for-profit organizations such as National Endowment for Science, Technology and the Arts (NESTA) contribute different innovation actors, including bringing industry, academic, social and government actors together to seek projects, funding, and trading opportunities and to influence government policy. For instance, the Creative Industries Policy and Evidence Centre (PEC), led by NESTA, provides research and recommendations to the UK's creative industry policies. Emerging themes such as innovation and sustainability, related to the creative economies, are discussed during NESTA research projects and public events.

Compared with the UK, China's animation industry shows a different growth path. Before 2000, most Chinese animation studios were subcontractors for western and Japanese companies. There were very limited original products and IPs. Since 2001, the Chinese government has launched a series of policies to support the domestic animation industry. The first 10 years were regarded as an incubation period, with policies fostering an atmosphere of creativity and innovation, providing subsidies and broadcasting channels, and funding start-ups and SMEs [56]. Clusters and animation industry parks emerged, with a range of IT companies, animation studios, trading agencies, services, and admin offices appearing. In 2015, there were 70 animation clusters in China, $70 \%-80 \%$ of which were supported by the central and local governments [57]. Clusters play an essential role by providing industry information, technology support, training, and communications platforms for SMEs [57]. Though the number of original products has increased, most products at this stage target young children [56]. Initially, due to the lack of IPs and knowledge, firms also launched online platforms to invite collaborators to share projects and solve problems together, which formed an open innovation model [17].

With mergers and acquisitions (M\&As) and strategic alliances, leading animation companies began to emerge in China, which integrated the supply chain and delivered a range of product and services. For example, Alpha Animation, a toy manufacturing company in Guangdong Province, developed strong alliances with world-class companies such as Disney and Japan Bandai, and formed a strong brand [58]. In 2015, it acquired the Chinese comic content company U17, moving towards animation design and production [58]. With internal IPs and partnership development, Alpha Animation became one of the largest 
companies in China in 2019 [58]. In 2017, among China's listed animation companies, character businesses such as the toy sector contributed $70 \%$ of the total profit. Large companies in China have also highlighted the importance of IP mechanization through forms of user service and entertainment such as theme parks [59].

Since 2013, online platforms such as Tencent and IQI have entered the animation industry. With capital and demand expansion, the industry chain has been further developed. Small studios and individual designers can share products to attract the mass market. Social innovation and user engagement have become new trends. In February 2018, the IQI animation App was officially launched, delivering cartoons, animation videos and other digital content on the mobile platform [56]. In 2018, Alibaba Cultural Entertainment Group announced its collaboration with Disney, enabling more than 1000 animation series to be accessed through Youku and OTT platforms [56]. The scale of animation product customers in China increased from 22.57 million in 2013 to 97.25 million in 2017, mainly due to the influence of internet-based mass innovation and the expansion of products towards user experience products [56]. Emerging internet comic companies, online animation platforms, cosplay performances, and animation festivals further link animation producers and society as a whole.

A summary is presented in Table 3, based on our findings on the UK's and China's animation industries, with detailed elements of CISs, OISs and OISs. Back in the early 2000s, the UK's animation industry was already well-established, with leading companies and IP generation both in-house and through partnerships demonstrating features of CISs. Since the ATR policy in 2013, there has been a blooming of SMEs, which collaboratively generate IPs. TV and online distributors have also actively engaged in IP management. Spillover effects of products and services have become new themes of OISs. Recently, with industry associations and non-for-profit organizations' involvement, social events and online platforms have brought the industry, the government, research and users together, forming features of SISs. In China, with limited knowledge resources and IPs initially, industry clusters began to be formed by the government from 2000 onwards to promote OISs, with cluster effects, infrastructure development, and SMEs' learning and collaboration observed. Then, through M\&As, strategic alliances, and resource integrating, large leading firms emerged, generating and mechanizing IPs along the value chain, showing an evolution towards CISs. Recently, user engagement, social media, and grassroots innovation are encouraged to create SISs.

Table 3. Features of three types of macro innovation systems in the animation industry.

\begin{tabular}{|c|c|c|c|}
\hline Value Chain & $\begin{array}{l}\text { Closed Innovation System } \\
\text { (CIS) }\end{array}$ & $\begin{array}{l}\text { Social Innovation System } \\
\text { (SIS) }\end{array}$ & $\begin{array}{l}\text { Open Innovation System } \\
\text { (OIS) }\end{array}$ \\
\hline Creation/design & $\begin{array}{l}\text { Large firms conducting R\&D } \\
\text { internally; } \\
\text { Large firms leading the } \\
\text { industry, with SMEs under the } \\
\text { roof; } \\
\text { IP protection and } \\
\text { management; } \\
\text { Co-developing products with } \\
\text { long-term supply partners; } \\
\text { Backward integration with } \\
\text { creation/design studios. }\end{array}$ & $\begin{array}{l}\text { General stakeholder } \\
\text { involvement (non-for-profit } \\
\text { organizations, industry, } \\
\text { university, government); } \\
\text { Products featuring social } \\
\text { needs; } \\
\text { Social innovation and } \\
\text { collective creation. }\end{array}$ & $\begin{array}{l}\text { Triple Helix innovation with } \\
\text { university involvement, e.g., } \\
\text { the UK screen industry; } \\
\text { Crowd sourcing and } \\
\text { innovation events; } \\
\text { Open innovation based on } \\
\text { digital platforms, led by large } \\
\text { companies; } \\
\text { Knowledge spillover effect. }\end{array}$ \\
\hline Manufacturing/production & $\begin{array}{l}\text { In-house production; } \\
\text { Long-term collaboration; } \\
\text { Outsourcing with strict } \\
\text { control. }\end{array}$ & $\begin{array}{l}\text { Industrial association and } \\
\text { NGOs' involvement for } \\
\text { standardization and social } \\
\text { concerns. }\end{array}$ & $\begin{array}{l}\text { Outsourcing and } \\
\text { subcontracting with multiple } \\
\text { partners; } \\
\text { Co-production among large } \\
\text { firms and SMEs on } \\
\text { digital platforms. }\end{array}$ \\
\hline
\end{tabular}


Table 3. Cont.

\begin{tabular}{|c|c|c|c|}
\hline Value Chain & $\begin{array}{l}\text { Closed Innovation System } \\
\text { (CIS) }\end{array}$ & $\begin{array}{l}\text { Social Innovation System } \\
\text { (SIS) }\end{array}$ & $\begin{array}{l}\text { Open Innovation System } \\
\text { (OIS) }\end{array}$ \\
\hline Distribution/marketing & $\begin{array}{l}\text { Distribution through major } \\
\text { online and offline media, e.g., } \\
\text { TV, Amazon; } \\
\text { Market and monetary } \\
\text { value delivery. }\end{array}$ & $\begin{array}{l}\text { Marketing with social events; } \\
\text { Social media and social } \\
\text { networks e.g., YouTube, } \\
\text { Twitter, Facebook }\end{array}$ & $\begin{array}{l}\text { Distribution through various } \\
\text { interactive forms, e.g., Netflix, } \\
\text { Amazon, YouTube, Twitter, } \\
\text { Facebook; } \\
\text { Crowd voting and user } \\
\text { engagement; } \\
\text { Using social media and } \\
\text { social networks. }\end{array}$ \\
\hline Communication/service & $\begin{array}{l}\text { Cross sector integration, e.g., } \\
\text { animation IP further } \\
\text { expanding towards the } \\
\text { gaming industry, consumer } \\
\text { products, theme parks, hotel } \\
\text { businesses, with IP control }\end{array}$ & $\begin{array}{l}\text { Services featuring social needs } \\
\text { and community engagement; } \\
\text { Considering user experience } \\
\text { in product development and } \\
\text { expansion; } \\
\text { Festivals to encourage } \\
\text { communication }\end{array}$ & $\begin{array}{l}\text { User-content creation; } \\
\text { University entrepreneurs; } \\
\text { Product spillover effect. }\end{array}$ \\
\hline
\end{tabular}

\subsection{Government Policies in the U.K's and China's Animation Industries}

The animation industry-related policies in the UK can be analyzed in Table 4 . From 2000 to 2010, polices mainly focused on the standardization of large companies' behaviors and IP protection. Starting from 2011, with publicly funded education and research institutions, infrastructure such as TV channels, knowledge sharing, and social engagement have been promoted. With the ATR policy in 2013 and related children's program and video game relief schemes, SMEs have developed rapidly. In 2014, this relief allowed over 500 productions to claim a stake in the annual GBP 15 million fund available from the UK government [5]. Statistics have shown a dramatic increase in the UK animation industry's innovation capability, due to the impact of the tax relief fund [5]. Recently, there has been more support from the government on R\&D and technology development.

Table 4. Analysis of animation industry-related policies in the UK.

\begin{tabular}{|c|c|}
\hline $\begin{array}{l}\text { Government Policy Instruments (S, D, E) with } \\
\text { Detailed Content }\end{array}$ & Impact on Macro Innovation Systems (CIS, SIS, OIS) \\
\hline $\begin{array}{l}\text { 2002. The Enterprise Act: Reviews mergers in the media } \\
\text { industry, to make sure that one owner does not control a } \\
\text { disproportionately large share of the industry [60]. }\end{array}$ & $\begin{array}{l}\text { This regulation standardizes practices of large firms in the } \\
\text { media industry. } \\
\text { (D6 } \rightarrow \text { CIS) }\end{array}$ \\
\hline $\begin{array}{l}\text { 2003. The Communications Act: It is the primary means by } \\
\text { which the digital industries are regulated. It set up Ofcom's } \\
\text { (UK's communications regulator) full powers [60]. }\end{array}$ & $\begin{array}{l}\text { This centralized policy standardizes the practices of the digital } \\
\text { industry. } \\
\text { (D6 } \rightarrow \text { CIS) }\end{array}$ \\
\hline $\begin{array}{l}\text { 2010. The Digital Economy Act: Measures to protect the rights } \\
\text { of copyright owners online; the Initial Obligations Code for } \\
\text { rights holders and ISPs (internet service providers) on how to } \\
\text { deal with internet piracy; the code for the functioning of the } \\
\text { mass notification system, which will require certain internet } \\
\text { ISPs to participate and will clarify the voluntary role copyright } \\
\text { owners will play [60]. }\end{array}$ & $\begin{array}{l}\text { The regulations aim to ensure IP protection, standardize } \\
\text { practices on digital platforms, and benefit large firms and SMEs } \\
\text { with IPs. Through measurements and benchmarks, IP } \\
\text { management can be more efficient and effective. } \\
\text { (E2 } \rightarrow \text { CIS) }\end{array}$ \\
\hline $\begin{array}{l}\text { 2011-2012. Funding the British Film Institute (BFI), the UK's } \\
\text { lead agency for film, to support film production, distribution, } \\
\text { education, audience development, and market research [60]. }\end{array}$ & $\begin{array}{l}\text { From } 2011 \text { to } 2012 \text {, the government funding of BFI amounted to } \\
\text { GBP } 20 \text { million, greatly supporting education, training, and } \\
\text { market research, and engaging more people in the film industry. } \\
\text { (S7, S8, E8 } \rightarrow \text { SIS) }\end{array}$ \\
\hline
\end{tabular}


Table 4. Cont.

\section{Government Policy Instruments (S, D, E) with Detailed Content}

2011. Setting up the Creative Industries Council: to provide regular dialogue between the government and the industry. The council focuses on areas where there are barriers to growth facing the sector, such as access to finance, skills, export markets, regulation, IP and infrastructure [60].)

2011. The Media Ownership (Radio and Cross Media) Order: Giving media businesses the freedom to enter new markets, particularly local TV [60].

2012. Funding the BFI Film Academy Network: the BFI delivers film-related courses at different locations in the UK. It aims to provide everyone with the opportunity to build a lifelong relationship with film; to create clear progression paths for talented young people; to ensure that film is celebrated and explored in formal education [60].

2012. The Local Digital Television Programme Services Order: Creating a local TV licensing regime [60].

2013. The multiplex operator (responsible for building and maintaining the technical infrastructure needed to broadcast local TV services) license was awarded to Ofcom. This is a significant milestone in moving the launch of each local TV channel forward [60].

2013 Creative industry tax reliefs: A group of 8 Corporation Tax reliefs that allow qualifying companies to claim deductions when calculating their taxable profits [61].

2013. Animation Tax Relief (ATR): Companies can claim ATR on an animation program if: the program passes the cultural test or qualifies as an official co-production; the program is intended for broadcast; at least $51 \%$ of the total core expenditure is on animation; at least $10 \%$ of the total production costs relate to activities in the UK [61].

2014. Children's Television Tax Relief (CTR): Companies can claim CTR if: the program passes the cultural test or qualifies as an official co-production; the program is intended for broadcast; the program must be for children, specifically, the primary audience is expected to be under the age of 15 ; at least $10 \%$ of the total production costs relate to activities in the UK [61].

2014. Video Games Tax Relief (VGTR): Companies can claim VGTR if: the video game is British; the video game is intended for supply; at least $25 \%$ of core expenditure is incurred on goods or services that are provided from within the European Economic Area (EEA) [61].

2014 Interaction of VGTR and Research and Development (R\&D) tax relief: Where video game SMEs' R\&D tax relief is claimed on a project, large companies can make claims under the large scheme [61].

\section{Impact on Macro Innovation Systems (CIS, SIS, OIS)}

The Creative Industrial Council is an informal forum. It breaks the barrier between sectors and companies, engaging large companies and SMEs to generate knowledge together, and provides infrastructure and service support. (D6, E1, E2, E3, E5 $\rightarrow$ OIS)

This policy can encourage more companies, including SMEs, to deliver products to the market smoothly. It also promotes product spillover effects through media.

(E3 $\rightarrow$ OIS)

In late 2012, the BFI received money from the Department for Education to create the BFI Film Academy Network. The government action further contributes to education, market research, the distribution of the film industry, public awareness of film knowledge and skills, and social engagement. $(\mathrm{S} 2, \mathrm{~S} 7, \mathrm{~S} 8 \rightarrow \mathrm{SIS})$

This policy can improve infrastructure and public services. $(\mathrm{E} 3 \rightarrow$ SIS)

It shows infrastructure support to facilitate the distribution of the animation industry. It also stimulates the market at a local level by expanding TV program accessibility. $(\mathrm{E} 3 \rightarrow$ SIS)

It highlights the importance of the creative industries, with favorable tax policies provided.

$(\mathrm{S} 3, \mathrm{E} 1 \rightarrow$ OIS)

With the ATR policy, the number of animation studios, including most SMEs, will grow.

$(\mathrm{S} 3, \mathrm{E} 1 \rightarrow$ OIS)

CTR is an extension of high-end television and animation relief. It promotes original designs, and collaboration between media and animation companies. Meanwhile, it also contributes to children's education and public service improvement.

(E3, E8 $\rightarrow$ SIS; S3, E1, E5 $\rightarrow$ OIS)

This policy encourages product spillover effects, from animation movies to the game industry and related services. It also facilitates alliances among animation studios and game software companies to co-create IP. $(\mathrm{S} 3, \mathrm{E} 1, \mathrm{E} 5 \rightarrow$ OIS)

This policy supports the original R\&D activities of the video game industry, which is closely related to the animation industry. It provides benefits to both large firms and SMEs. $(\mathrm{S} 3, \mathrm{E} 1 \rightarrow$ OIS; S3, E1 $\rightarrow$ CIS)

While the UK government mainly facilitates alliances among industries, universities and society, Chinese government policies show more centralized support at the beginning of 2000. As shown in Table 5, with an initial lack of IPs and leading firms, supply-side policies were used to finance R\&D and productions. Infrastructure was then built to assist the distribution to market. From 2006, China's animation industry has shown high degrees of open innovation, with government funding promoting industry clusters, administration 
and service agencies, and SMEs' co-generating knowledge. From 2009, their policies have gradually moved towards IP protection and management, and funding and rewarding key brands and leading large firms. Since 2017, with the government promoting mobile animation platforms and social events, social innovation has emerged as a new theme.

Table 5. Analysis of animation industry-related policies in China.

\begin{tabular}{l} 
Government Policy Instruments (S, D, E) with \\
Detailed Content \\
\hline 2000. Notice on strengthening the introduction and \\
broadcasting of animated cartoons. \\
All TV stations must broadcast 10 min of animated cartoons \\
every day, with $60 \%$ being domestic-made [62]. \\
2002. The development plan of the film and television \\
animation industries during the "10th Five-Year Plan" period. \\
It highlights the industry paths of nationalization, \\
popularization and industrialization [62].
\end{tabular}

2004. Notice on subject planning of domestic TV animations. The Beijing animation channel, Shanghai cartoon TV, and Hunan Golden Eagle cartoon TV are approved as animation channels [62].

2005. Notice on tax policy issues concerning the autocratic reform of cultural institutions into enterprises.

Enterprises engaged in animation-related creation, production, and distribution can be exempted from the corporate income $\operatorname{tax}[62]$.

\section{Impact on Macro Innovation System (CIS, SIS, OIS)}

This is centralized regulation, with the aim of promoting original productions in general.

$($ E2 $\rightarrow$ OIS)

This policy continuously addresses the importance of the animation industry at the strategic level, promoting innovation and public support of the animation industry. $(\mathrm{E} 2 \rightarrow$ OIS)

This policy shows infrastructure support. With animation-featuring TV channels, animation products can be distributed to the mass market. It also links animation producers with distributors for collaboration. $(\mathrm{E} 3 \rightarrow \mathrm{OIS})$

As a typical supply-side policy, the tax exemption scheme supports the creation of knowledge. SMEs (due to almost no large companies existing) including software, comic book, animation and service companies, can be more actively engaged in innovation and creating IPs.

$(\mathrm{S} 3 \rightarrow \mathrm{OIS})$

2005. Specific measures to promote the development of animation creation in China.

Encouraging TV houses to broadcast domestic animation during 17:00 and 21:00. The total amount of domestic animation broadcasting should not be less than $60 \%$ [62].

2006. Some opinions on supporting the development of the domestic animation industry

The central government set up special funds to support the development of original animation works. It encourages social capital to enter the animation industry. Enterprises that open up their own production of animation products can enjoy exemption of the value-added tax and the corporate income tax. Eligible SMEs which develop technology innovation can apply for SMEs' science and technology fund [62].

2006-2012. Creating animation industry parks across China, with support from local governments. Examples are Supplementary opinions on encouraging and supporting the development of animation and game industry (Hangzhou government), Measures for fund management for the development of animation industry in Xiamen (Xiamen government), Preferential policies for Beijing digital entertainment industry base (Beijing government) [62].

2008. Management measures for the recognition of animation enterprises.

The standards and procedures for the identification of animation enterprises are stipulated [62].
This policy has, in general, supported original production, with protection from competition from foreign products conferred. (E3 $\rightarrow$ OIS)

This is one of the most important policies regarding the Chinese animation industry. SMEs' innovation is encouraged with resource sharing, learning, and exchange. Direct funding and favorable tax programs result in more companies involved in original R\&D and technology innovation. Social capital further provides chances for SMEs in addition to government funds. (S1, S2, S3, S5 $\rightarrow$ OIS)

These series of local government policies are to respond to central government guidance on the development of the animation industry's focus on supply support. Direct funding to R\&D projects, subsidies to SMEs, alliances between the industry and universities, training, research center establishment, administration and service improvements, and clusters are new themes of innovation. University-industry collaboration is supported by many local governments. $(\mathrm{S} 1, \mathrm{~S} 2, \mathrm{~S} 3, \mathrm{~S} 4, \mathrm{~S} 5, \mathrm{~S} 6, \mathrm{~S} 7, \mathrm{~S} 8, \mathrm{D} 5, \mathrm{E} 3 \rightarrow \mathrm{OIS})$

With the number of SMEs increasing, this policy helps industry convenience and standardization.

$($ D6 $\rightarrow$ OIS; D6 $\rightarrow$ CIS) 
Table 5. Cont.

$\begin{aligned} & \text { Government Policy Instruments (S, D, E) with } \\ & \text { Detailed Content }\end{aligned} \quad$ Impact on Macro Innovation System (CIS, SIS, OIS)

2009. Notice of the State Administration for Industry and Commerce of the Ministry of Culture on the special rectification of the animation market.

The protection of animation derivatives, trading products, key animation products, and other regulatory work are deployed [62].

2011. Notice on the business tax policy of value-added tax to support the development of the animation industry. This extended the relevant tax incentives until the end of 2012 and brought animation copyright trading into the scope of preferential treatment [62].
2012. The "12th five-Year Plan" for creative industries. The animation industry is listed as one of the 11 key industries. It is proposed that "by 2015, the value added of the animation industry will exceed 30 billion yuan, creating 5-10 domestic animation brands and key animation enterprises with strong competitiveness and influence in the world." [62]

2013. National animation brand construction and protection plan.

Identifying 20 animation brands including the "Happy goat and grey wolf" and announcing the standards of mobile animation [62].
Trends of resource integration, and product and brand convergence aiming at high quality and value-added activities are formed based on this regulation.

$(\mathrm{D} 6, \mathrm{E} 2 \rightarrow \mathrm{CIS})$

Apart from continuously supporting the animation industry's innovation and production, this policy highlighted IP protection, driving the movement towards closed innovation and resource integration. $(\mathrm{S} 3 \rightarrow \mathrm{CIS})$

This policy indicates a strategic change from OISs towards CISs with the resource integrating, funding and promoting of leading companies. Through M\&A and collaboration, leading large firms are gradually formed which have control of value chains, technology and IPs.

$(\mathrm{S} 2, \mathrm{E} 2 \rightarrow \mathrm{CIS})$

The identification and rewarding of top animation brands shows government support on leading large companies. With brand promotion, the supply chain can be further integrated. With mobile infrastructure support, the public can engage with the industry more easily.

$(\mathrm{S} 2 \rightarrow \mathrm{CIS}, \mathrm{S} 6$, E3 $\rightarrow$ SIS)

2017. The Ministry of Culture's planning for cultural development and reform in the 13th Five-Year Period. Promoting China's International Network Culture Expo, China's International Animation and Games Fair and other key creative industries events. Supporting original animation production and brands featuring the national culture, and promoting mobile phone animation standards [62].
The policy shows the importance of cross-sectorial communication and information exchange. Through events, it also involves service agencies and society.

$(\mathrm{E} 5, \mathrm{E} 8 \rightarrow \mathrm{SIS})$

\subsection{Dynamic View of the Macro Innovation System}

From the above analysis, the UK's animation industry shows the features of closed innovation (leading firms who own IPs) $\rightarrow$ open innovation (SMEs) $\rightarrow$ social innovation (interaction among large firms, SMEs, and society) almost simultaneously. China's industry follows the paths of open innovation (SMEs learning and sharing knowledge) $\rightarrow$ closed innovation (leading firms through resource integration) $\rightarrow$ social innovation (societal contributions). Based on the OIES model [7], a framework can be further developed, which is shown in Figure 2. In particular, the role of government is identified in transforming three innovation system patterns.

Back in the early 2000s, the UK government adopted a tax relief program to improve the regulation environment of the animation industry, which was then led by large firms (D6, E2, E1). Moving towards OISs, there were supply-side tax and infrastructure support policies (S3, S6), in combination with environmental-side policies (E1, E2, E3, E5). It is seen that once the industry is already established, the government can, through environmentalside policies, act as a catalyst to promote idea exchange between sectors, innovation actors and society through various platforms. In China, with limited resources, the government issued supply-side policies in the early 2000s to promote SME innovation. Quotas and protections, favorable tax policies, cluster funding and direct funding quickly drove the industry (S1, S2, S3, S4, S5, S6, S7, S8). The purpose was to stimulate knowledge creation and sharing, rather than protecting IPs. This was later directed towards value chain integration and IP management, with supply-side tax policies and funding, and IP protection 
regulations (S2, S3, D6, E2). With resource accumulation and the emergence of leading firms, China's animation industry in 2012 showed similarities to the UK's in the early 2000s. To date, demand-side policies are not obvious in the UK and China. However, as macro innovation systems are moving towards SISs in both countries, environment-related polices, including infrastructure and public education (E3, E8), alliances among industries and society (E5), and new infrastructure such as mobile communication platform improvement (E3), can be the next steps.

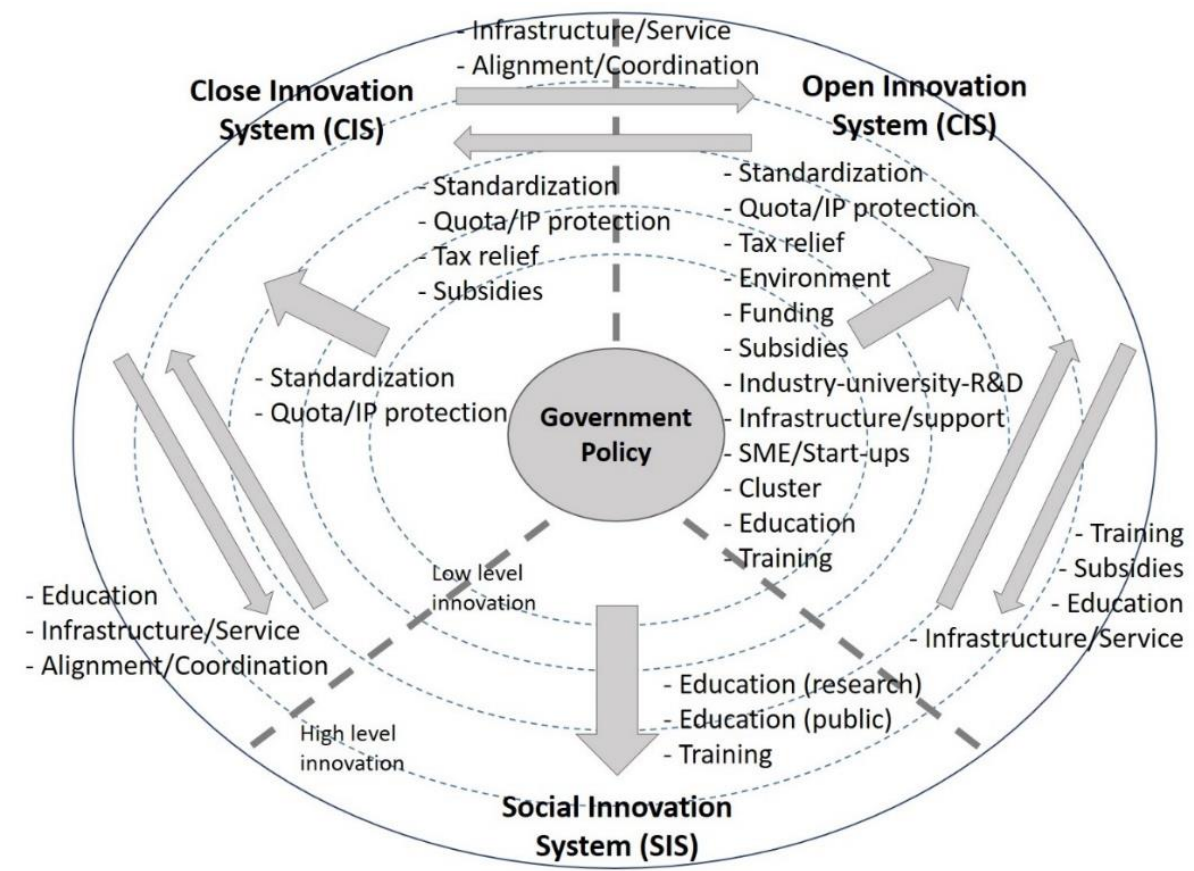

Figure 2. Macro dynamic evolution of the UK's and China's animation industries.

\section{Conclusions}

The creative industries have experienced significant transformations in recent times, with features of flexibility, user engagement, technology advancement, open platforms and digitalization, and project-based short life cycles observed. These transformations have happened particularly in the animation sector, which has extended its value chain from design and production to commercialization, delivering both tangible products and intangible services. Online media and games, tablet and mobile phones, and user experiences can all be connected by digital platforms, which reforms the sector in terms of technology and business model innovation. While traditionally, companies have displayed closed innovation and IP protection, open innovation emphasizes knowledge exchange between internal and external sources. Knowledge spillover, product extensions, and user contributions are further innovation effects of the creative industries.

Through in-depth studies of the UK's and China's animation sectors, this paper aims to determine the impact of government policy on macro dynamic innovation systems. There are three main findings. (1) The macro dynamic innovation model, OIES, can be implemented in the animation industry, with features along the value chain showing different patterns of CISs, OISs and SISs. (2) The industry's innovation systems have experienced dynamic evolution in recent times. In the UK, there is a trend from CISs to OISs and SISs, but these transformations can happen simultaneously. In China, with resource accumulation, transformation from OISs to leading companies' CISs is observed. (3) Government policies can facilitate changes of macro dynamic innovation systems. Supply-side instruments such as favorable tax policies and funding, cluster support, and training and education can promote OISs. Especially at early stages where innovation resources are limited, governments can play a dominant role. As the industry becomes mature, governments can act 
as facilitators to promote idea exchange across innovation actors. Service providers and industrial associations are also intermediaries to innovation. When an industry reaches the convergence stage, environmental polices such as IP protection can encourage CISs with value chain integration and reconfiguration, moving to the next level of innovation. Cross-sectorial integration and coordination can be achieved through public sourcing and contributions, demonstrating a new trend of SISs. At this point, governments can guide the industry's direction through standardization, soft-law and governance, leading to self-regulation.

Our findings enrich the OIES model, contributing to the theory of government innovation policy in the context of creative industries. This research can be useful to practitioners and policy makers, including countries where the creative economies have already demonstrated competitive advantages, and countries where the sectors are emerging but challenged by resource constraints. Based on the theory framework, it is recommended that the UK government should continuously focus on bottom-up policies in order to capture social value and deliver products and services to the public. Technology infrastructure improvement and links among various innovation actors are also future directions that should be pursued.

There are some limitations of this research. First, it mainly focuses on the role of government policy in the UK's and China's creative industries' innovation systems, and the main method of data collection is by secondary document review. The method can be improved through the use of some empirical studies, such as interviewing companies and government officials. Other countries' practices need to be studied and compared to enrich the findings. Second, more macro factors, such as technological, industrial, social, and cultural elements can be further investigated, which would help to generate a more holistic understanding of the macro dynamic innovation system. Thirdly, though macro factors provide policy support and social context, micro factors can indicate the innovation performance at organizational levels. Topics such as changes of management, the organizational culture, learning processes, business model innovation and digitalization can be essential. These micro factors can be linked with the macro factors through more in-depth studies. Thus, future research could involve micro level empirical studies, such as case studies, in order to enrich the understanding of creative industries' innovation from product, service and business model perspectives.

Funding: This research received no external funding.

Institutional Review Board Statement: Not applicable.

Informed Consent Statement: Not applicable.

Data Availability Statement: Not applicable.

Acknowledgments: This study is part of the Society of Open Innovation: Technology, Market and Complexity (SOI) Open Innovation Academy researcher internship from September 2019 to August 2020. The author would like to thank SOI for supporting the paper's development.

Conflicts of Interest: The author declares no conflict of interest.

\section{References}

1. Giarini, O. The globalization of service in economic theory and economic practice: Some conceptual issues. In Trading Services in the Global Economy; Cuadrado-Roura, J.R., Rubalcaba-Bermejo, L., Bryson, J.R., Eds.; Edward Elgar: Cheltenham, UK, 2002; pp. 58-77.

2. DCMS. Creative Industries Mapping Documents 1998; DCMS: London, UK. Available online: https://www.gov.uk/government/ publications/creative-industries-mapping-documents-1998 (accessed on 4 August 2019).

3. DCMS. Creative Industries Mapping Documents; DCMS: London, UK, 2001. Available online: https://www.gov.uk/government/ publications/creative-industries-mapping-documents-2001 (accessed on 4 August 2019).

4. UNCTAD. Creative Economy Bucks the Trend, Grows Despite Slowdown in Global Trade. 2019. Available online: https: // unctad.org/en/pages/PressRelease.aspx?OriginalVersionID=499 (accessed on 4 August 2019).

5. Lumina. UK Animation on the Rise. 2017. Available online: http://luminasearch.com/research/animation-on-the-rise/ (accessed on 4 August 2019). 
6. Messerlin, P.; Parc, J. The effect of screen quotas and subsidy regime on cultural industry: A case study of French and Korean film industries. J. Int. Bus. Econ. 2014, 15, 57-73.

7. Yun, J.J. How do we conquer the growth limits of capitalism? Schumpeterian dynamics of open innovation. J. Open Innov. Technol. Mark. Complex. 2015, 1, 1-20. [CrossRef]

8. Yun, J.J.; Liu, Z. Micro and macro dynamics of open innovation with quadruple-helix. Sustainability 2019, 11, 3301. [CrossRef]

9. Chesbrough, H. Open Innovation: The New Imperative for Creating and Profiting from Technology; Harvard Business School Press: Cambridge, MA, USA, 2013.

10. Chesbrough, H.; Brunswicker, S. A fad or a phenomenon?: The adoption of open innovation practices in large firms. Res. Technol. Manag. 2014, 57, 16-25.

11. Ayob, N.; Teasdale, S.; Fagan, K. How social innovation 'came to be': Tracing the evolution of a contested concept. J. Soc. Policy 2016, 45, 635-653. [CrossRef]

12. Bogers, M.; Chesbrough, H.; Moedas, C. Open innovation: Research, practices, and policies. Calif. Manag. Rev. 2018, 60,5-16. [CrossRef]

13. Moore, J.F. Predators and prey: A new ecology of competition. Harv. Bus. Rev. 1993, 71, 75-86.

14. Adner, R. The Wide Lens: A New Strategy for Innovation; Penguin: London, UK, 2012.

15. Beraud, P.; du Castel, V.; Cormerais, F. Open innovation, economy of contribution and the territorial dynamics of creative industries. J. Innov. Econ. 2012, 10, 81-105. [CrossRef]

16. Dahlander, L.; Gann, D.M. How open is innovation? Res. Policy 2010, 39, 699-709. [CrossRef]

17. Ma, L.; Qian, C.; Liu, Z.; Zhu, Y. Exploring the innovation system of the animation industry: Case study of a Chinese company. Sustainability 2018, 10, 3213. [CrossRef]

18. Santagata, W. Cultural districts, property rights and sustainable economic growth. Int. J. Urban Reg. Res. 2002, 26, 9-23. [CrossRef]

19. Banks, M.; Hesmondhalgh, D. Looking for work in creative industries policy. Int. J. Cult. Policy 2009, 15, 415-430. [CrossRef]

20. Edler, J.; Georghiou, L. Public procurement and innovation: Resurrecting the demand side. Res. Policy 2007, 36, 949-963. [CrossRef]

21. Ma, L.; Jiang, M.; Yu, K.; Gan, J. A Study on Regional Innovation Policy under Innovation Paradigm 30: A Case of Jiangsu Province in China. In Proceedings of the 2016 Portland International Conference on Management of Engineering and Technology (PICMET 2016), Honolulu, HI, USA, 4-8 September 2016; pp. 1055-1064.

22. OECD. Demand-Side Innovation Policies; OECD Publishing: Paris, France, 2011.

23. Qu, L.; Li, Y. Research on industrial policy from the perspective of demand-side open innovation: A case study of Shenzhen new energy vehicle industry. J. Open Innov. Technol. Mark. Complex 2019, 5, 31. [CrossRef]

24. Almgren, R.; Skobelev, D. Evolution of technology and technology governance. J. Open Innov. Technol. Mark. Complex 2020, 6, 22. [CrossRef]

25. Li, F.; Butel, L.; Wang, P. Innovation policy configuration-A comparative study of Russia and China. Policy Stud. 2017, 38, 311-338. [CrossRef]

26. Schot, J.; Steinmueller, W.E. Three frames for innovation policy: R\&D, systems of innovation and transformative change. Res. Policy 2018, 47, 1554-1567.

27. Grillitsch, M.; Hansen, T.; Coenen, L.; Miorner, J.; Moodysson, J. Innovation policy for system-wide transformation: The case of strategic innovation programmes (SIPs) in Sweden. Res. Policy 2019, 48, 1048-1061. [CrossRef]

28. Phills, J.A.; Deiglmeier, K.; Miller, D.T. Rediscovering social innovation. Stanf. Soc. Innov. Rev. 2008, 6, $34-43$.

29. Flew, T. Global Creative Industries; Polity Press: Cambridge, UK, 2013.

30. Ritman, A. U.K. Film Industry Sees Record Spending from Hollywood Production in 2016. The Hollywood Reporter. 2017. Available online: https:/ / www.hollywoodreporter.com/news/uk-film-industry-sees-record-spending-hollywood-productions2016-968843 (accessed on 12 September 2019).

31. Santoro, G.; Bresciani, S.; Papa, A. Collaborative modes with Cultural and Creative Industries and innovation performance: The moderating role of heterogeneous sources of knowledge and absorptive capacity. Technovation 2020, 92-93, 102040. [CrossRef]

32. Chandra, T. Mapping knowledge management system within literatures of creative industry. J. Manag. Inf. Decis. Sci. 2019, $22,213-222$.

33. Li, F. The digital transformation of business models in the creative industries: A holistic framework and emerging trends. Technovation 2020, 92-93, 102012.

34. Landoni, P.; Dell'era, C.; Frattini, F.; Petruzzelli, A.M.; Verganti, R.; Manelli, L. Business model innovation in cultural and creative industries: Insights from three leading mobile gaming firms. Technovation 2020, 92-93, 102084.

35. Salvador, E.; Simon, J.; Benghozi, P. Facing Disruption: The Cinema Value Chain in the Digital Age. Int. J. Arts Manag. 2019, 22, 25-40.

36. Yamada, J.; Yamashita, M. Entrepreneurs' Intentions and Partnership Towards Innovation: Evidence from the Japanese Film Industry. Creat. Innov. Manag. 2006, 15, 258-267. [CrossRef]

37. Lassen, A.H.; Maureen, M.; Ljungberg, D. Knowledge-intensive entrepreneurship in manufacturing and creative industries: Same, same, but different. Creat. Innov. Manag. 2018, 27, 284-294. [CrossRef]

38. Hotho, S.; Champion, K. Small businesses in the new creative industries: Innovation as a people management challenge. Manag. Decis. 2011, 49, 29-54. [CrossRef] 
39. Mossig, I. Regional Employment Growth in the Cultural and Creative Industries in Germany 2003-2008. Eur. Plan. Stud. 2011, 19, 967-990. [CrossRef]

40. Innocenti, N.; Lazzeretti, L. Do the creative industries support growth and innovation in the wider economy? Industry relatedness and employment growth in Italy. Ind. Innov. 2019, 26, 1152-1173. [CrossRef]

41. Potts, J. Why creative industries matter to economic evolution. Econ. Innov. New Technol. 2009, 18, 663-673. [CrossRef]

42. Boix-Domenech, R.; Soler-Marco, V. Creative service industries and regional productivity. Pap. Reg. Sci. 2017, 96, 261-279. [CrossRef]

43. Oyekunle, A.O.; Sirayi, M. The role of creative industries as a driver for a sustainable economy: A case of South Africa. Creat. Ind. J. 2018, 11, 225-244.

44. Klement, B.; Strambach, S. Innovation in Creative Industries: Does (Related) Variety Matter for the Creativity of Urban Music Scenes? Econ. Geogr. 2019, 95, 385-417. [CrossRef]

45. Feuls, M. Understanding culinary innovation as relational: Insights from Tarde's relational sociology. Creat. Innov. Manag. 2018, 27, 161-168. [CrossRef]

46. Zhou, J.; Li, J.; Jiao, H.; Qiu, H.; Liu, Z. The more funding the better? The moderating role of knowledge stock on the effects of different government-funded research projects on firm innovation in Chinese cultural and creative industries. Technovation 2020, 92-93, 102059. [CrossRef]

47. Lee, N.; Drever, L. The Creative Industries, Creative Occupations and Innovation in London. Eur. Plan. Stud. 2013, 21, 1977-1997. [CrossRef]

48. Liu, H.; Silva, E. Examining the dynamics of the interaction between the development of creative industries and urban spatial structure by agent-based modelling: A case study of Nanjing, China. Urban Stud. 2018, 55, 1013-1032. [CrossRef]

49. Lee, C.B. Cultural Policy and Governance: Reviewing Policies Related to Cultural and Creative Industries Implemented by the Central Government of Taiwan Between 2002 and 2012. Rev. Policy Rep. 2015, 32, 465-484. [CrossRef]

50. Comunian, R.; Taylor, C.; Smith, D. The Role of Universities in the Regional Creative Economies of the UK: Hidden Protagonists and the Challenge of Knowledge Transfer. Eur. Plan. Stud. 2014, 22, 2456-2476. [CrossRef]

51. Braun, V.; Clarke, V. Using thematic analysis in psychology. Qual. Res. Psychol. 2006, 3, 77-101. [CrossRef]

52. BFI. Screen Business: How Screen Sector Tax Reliefs Power Economic Growth across the U.K. 2018. Available online: https:// www.bfi.org.uk/sites/bfi.org.uk/files/downloads/screen-business-full-report-2018-10-08.pdf (accessed on 20 September 2019).

53. British Council. U.K. Animation. 2018. Available online: http://film.britishcouncil.org/docs/UKAnimationCatalogue_15288047 27.pdf (accessed on 20 September 2019).

54. ANIMATION UK. The UK's Animation Sector: In Profile. 2018. Available online: https://www.animationuk.org/subpages/theuks-animation-sector-in-profile/?section=industry (accessed on 20 September 2019).

55. LIAF. About the London International Animation Festival. 2019. Available online: http://www.liaf.org.uk/about/ (accessed on 20 September 2019).

56. CGB (Chinabaogao.com). Analysis of the Development Process and Profit Model of China's Animation Industry. 2018. Available online: http:/ / market.chinabaogao.com/it/0411303512018.html (accessed on 20 September 2019).

57. Liu, Z. The current business performance of the Chinese animation industry: Key structure and emerging themes. Int. J. Cult. Creat. Ind. 2015, 2, 42-53.

58. Alpha Animation. About Alpha Animation. 2019. Available online: https://www.gdalpha.com/about/index.html (accessed on 20 September 2019).

59. Sohu. Interpretation of the Revenue of Major Animation Companies in China. 2018. Available online: http://www.sohu.com/a/ 230105371_115832 (accessed on 28 September 2019).

60. DCMS. 2010 to 2015 Government Policy: Media and Creative Industries. 2015. Available online: https://www.gov.uk/ government/publications /2010-to-2015-government-policy-media-and-creative-industries/2010-to-2015-government-policymedia-and-creative-industries (accessed on 29 September 2019).

61. GOV.UK. Corporation Tax: Creative Industry Tax Reliefs. 2018. Available online: https://www.gov.uk/guidance/corporationtax-creative-industry-tax-reliefs (accessed on 29 September 2019).

62. Askci.com. Comic Industry Policy Summary and Interpretation in Different Parts of China. 2018. Available online: http: //www.askci.com/news / finance/20180115/162850116068.shtml (accessed on 20 September 2019). 